\title{
PYLORIC STENOSIS BEFORE AND AFTER RAMSTEDT*
}

\author{
BY
}

\author{
SELWYN TAYLOR \\ From King's College Hospital, Belgrave Hospital for Children and the Postgraduate Medical School of London
}

It is a remarkable fact that a condition which occurs so commonly and is so easily diagnosed as congenital hypertrophic pyloric stenosis should only have been recognized in this country about 50 years ago. There are a few isolated accounts of the condition in the earlier literature (Patrick Blair in 1717, Christopher Weber, 1758, and Williamson, of Edinburgh, in 1841). It was, however, Hirschsprung of Copenhagen (1888) who first described the disease as we know it, illustrating his account with two case histories, relating these to the post-mortem findings.

In 1898 in London, Edmund Cautley, physician to the Belgrave Hospital for Children, presented the records of two cases of pyloric stenosis to the Medico-Chirurgical Society (later the Royal Society of Medicine); for the next 20 years he was to devote a great deal of time and energy to the problem (Cautley, 1899; Cautley and Dent, 1903; Cautley, $1904,1906,1908)$. It is interesting to trace the evolution of the treatment of this condition through the methods which he employed, or which he pursuaded surgeons to employ for him, and about which he wrote so carefully. I am able to do this through the courtesy of Mr. Ramsay, lately senior surgeon at the Belgrave Hospital, who generously bequeathed me his records and papers and those of Dr. Cautley relating to pyloric stenosis.

Treatment of pyloric stenosis in those early days was of three kinds, dilatation of the pylorus, various forms of pyloroplasty and gastro-enterostomy (Mack, 1942).

Dilatation. In 1884 Loreta, in Italy, had devised an operation for treating pyloric stenosis in adults. He incised the distal stomach and forced one or two fingers through the pylorus, thus stretching it open. It was an operation attended by uncertain results, but two surgeons in this country adapted it for use in infants with some success. In Glasgow, Nicoll $(1900,1904)$ used a mechanical dilator introduced

* Lecture to the Fifth Annual Meeting of the British Association of Paediatric Surgeons in London on July 23, 1958. through the stomach, but, being dissatisfied with the results, added a gastro-enterostomy. 'In London Burghard (1906), of King's College Hospital, became extremely successful with this technique. He used a vertical mid-line incision to expose the stomach, held the pylorus between the fingers of the left hand and introduced a series of Hegar's dilators through an incision in the stomach until the muscle coat was felt suddenly to give way. When divulsion occurred anteriorly, this could be seen beneath the serosal layer. Probably this was the most successful surgical treatment of pyloric stenosis at that time.

Pyloroplasty. This method of treatment was introduced by Dr. Cautley's surgical colleague, Clinton Dent (Cautley and Dent, 1903) at the Belgrave Hospital using a technique previously employed in adults by von Heineke and von Mikulicz. Dent's first successful operations were on June 10 and August 19, 1902, one of the patients being a physician's son. It still surprises me how frequently the condition is encountered in doctor's families. Dent had 10 successes and two deaths in the next five years, better results than anyone else could report.

Pyloroplasty is popularly associated with the name of the French surgeon Fredet (Fredet and Guillemot, 1910; Fredet and Farret, 1912; Fredet and Tixier, 1912), and his particular contribution was incising the muscular coat, leaving the mucosa intact (extramucous division) since he realized the danger of soiling the peritoneal cavity. He, however, sutured the muscularis transversely, as in the classical form of pyloroplasty, his first extra-mucous pyloroplasty being performed on October 12, 1907 . In Germany, Weber $(1909,1910)$ independently evolved an almost identical technique, his first successful operation being on December 3, 1908. Fredet was apparently never enthusiastic about his extra-mucous pyloroplasty and continued to use gastro-enterostomy as the method of choice for treating pyloric stenosis until 1921. 
Nicoll of Glasgow, who seems never to have obtained rightful credit for his work, also evolved a form of extra-mucous pyloroplasty which he did after the V-Y fashion and described as early as 1906. He had five successes out of six patients treated by this method; he stressed the importance of not opening the mucosa, but always combined it with a Loreta dilatation (Nicoll, 1910).

Gastro-enterostomy. This operation was still being used by most surgeons in the early years of the century for treating pyloric stenosis. The mortality rate was usually $50 \%$ or more, but the patients submitted to operation were in poor condition and little was known at this time about fluid balance. It appears that the stenosis persisted in many of these patients much longer than in those who were treated by some kind of surgical attack upon the pylorus itself. There is a wealth of interesting papers published on this subject over the last 40 years.

We come now to Dr. Conrad Ramstedt of Münster, who on August 23, 1911, performed the first operation after the fashion which most of us still follow to this day. I am delighted to tell you that Dr. Ramstedt is still alive and, at the age of 91 , wrote me a vigorous and interesting letter only a few months ago. Until he was 80 he was operating regularly and was only stopped then by failing eyesight. As so many accounts of the evolution of this operation have appeared, I quote now a translation of part of a letter from him, written in 1957 to Dr. Pollock, in which he describes how he came to perform pyloromyotomy. He had been invited by the paediatrician at the children's hospital in Münster to treat congenital pyloric stenosis in the first-born son of a distinguished and noble family in the district; this was the first example of the condition he had ever seen. Having reviewed the various methods available he decided to perform a pyloroplasty by the extra-mucosal method:

\footnotetext{
'At the laparotomy on August 23, 1911, I was astonished at the pyloric tumour as thick as my thumb. After I had split the tumour down to the mucosa for a distance of about $2 \mathrm{~cm}$., I had the impression that the stenosis had been relieved. I still tried, however, to accomplish the plastic procedure by transverse suture of the muscle edges. However, the tension on the sutures was so very strong that the first one cut through immediately. Then the thought shot through my head, "A plastic alteration of the cut edges is completely unnecessary; the stenosis seems to be already relieved by a simple splitting of the pyloric muscle and coincidently the spasm as well, which is the characteristic basis of
}

the disease." I did not complete the plastic operation on the muscle which had been originally planned, but left the cut gaping, covering it with a tab of omentum for safety's sake and ended the operation. The little one vomited a few times for the first few days which I attributed to the sutures placed at the beginning, but he recovered promptly and completely to the great joy of his parents.'

Professor Ramstedt performed this operation for the second time on June 18, 1912, and in September of that year reported these two cases to the Natural Science Assembly at Münster (Ramstedt, 1912, 1913).

It must have puzzled many who have read his papers why Professor Ramstedt spells his name with two ' $m$ 's in the early accounts of the disease and later with only one. We are indebted to Dr. Pollock of Los Angeles (Pollock and Norris, 1957; Pollock, Norris and Gordon, 1957) for the explanation. It appears that in Germany, prior to the first World War, it was usual for the family records to be part of the Church records for occasions such as births and marriages. Prior to the first World War Ramstedt had spelt his name with two 'm's, but having become interested in his own genealogy, he was surprised to discover that his grandfather had apparently made an error in the entries in the Church records and that the family name had originally been spelt with only one ' $\mathrm{m}$ '. He, therefore, after 1920 changed the spelling of his name to conform with the earlier records.

Ramstedt himself described his operation as a pyloromyotomy and this remains much the best word to describe what is carried out. For those who are addicted to eponymous nomenclature, I hope I have made it clear that the rightful title is Ramstedt's operation and not Fredet-Ramstedt or even Fredet-Weber-Ramstedt.

The spread of Ramstedt's operation to other parts of the world is interesting. In the U.S.A. it was adopted very quickly, enthusiastically and successfully, and quite considerable series were reported from there by 1916. In this country the 1914-1918 war delayed its adoption and it was not until the end of the war that Dr. Cautley at the Belgrave Hospital asked his surgical colleague, Mr. Ramsay, to perform the operation. As a result the first Ramstedt operation at the hospital was on July 16, 1918. The child collapsed and died a week later, although at autopsy the stenosis was shown to have been relieved. On October 29, 1918, Ramstedt's operation was performed for the second time with complete success. Subsequently Ramsay (1919, 1921) performed this operation more than 200 times at the Belgrave Hospital with remarkable success. 


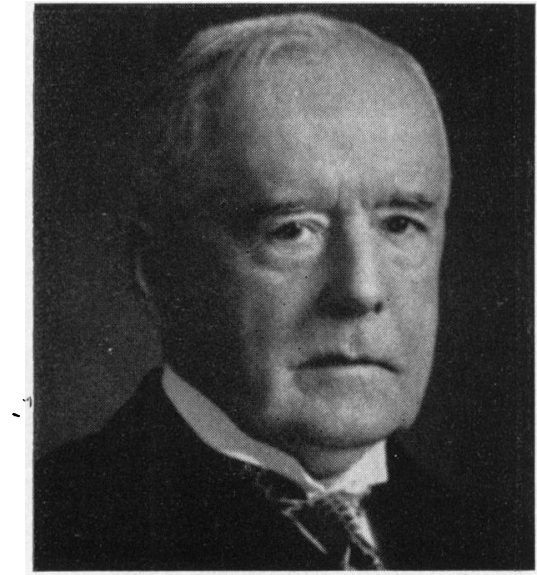

Edmund Cautley (1864-1944), Physician. Belgrave Hospital for Children, London.
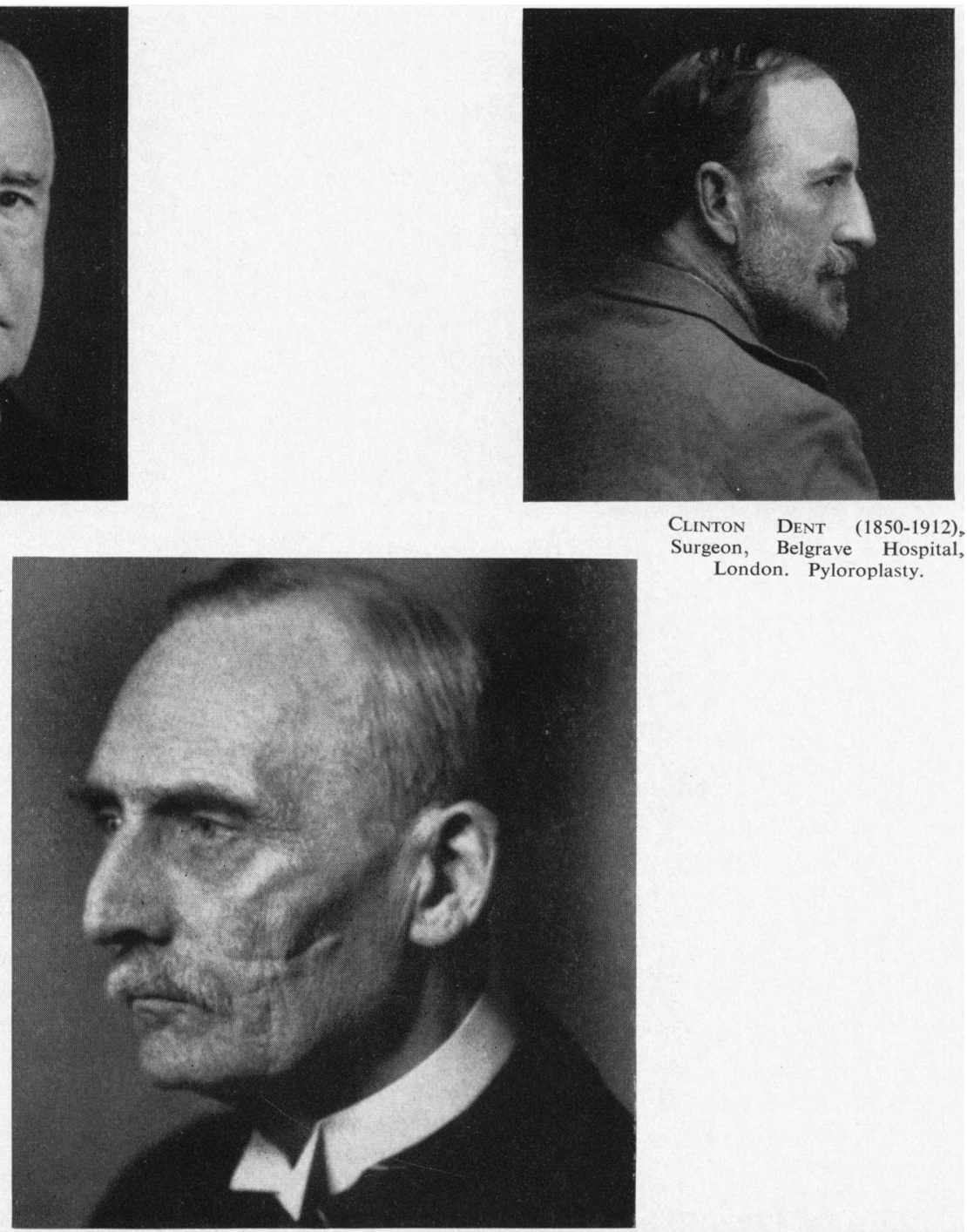
London. Pyloroplasty.

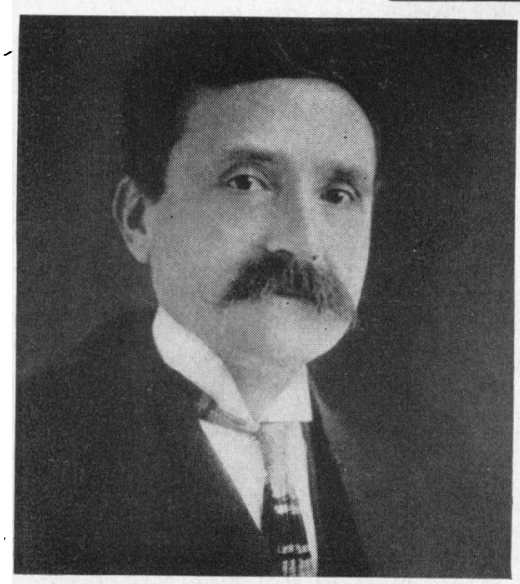

Pierre Fredet (1870-1946) of Paris. Extramucous pyloroplasty.

\section{CONRAD RAMSTEDT (1867- ) of Münster. Pyloromyotomy.}

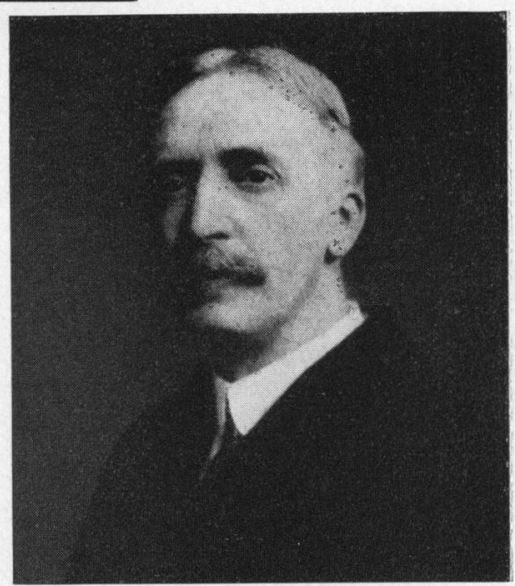

JAMES NICOLL (1864-1921) of Glasgow. V-Y pyloroplasty. 
It speaks much for his skill that the notes state that he performed his first Ramstedt's operation in precisely seven minutes.

Since the cause of pyloric stenosis in infancy is unknown the treatment, whether by means of drugs or by operation, remains empirical. From the mass of papers appearing on this subject, that of Friesen, Boley and Miller (1956) in Kansas appears to offer the most rewarding approach. They studied the development of the myenteric nervous plexus in the normal human foetal pylorus and compared the findings at full term with those of biopsy carried out at Ramstedt's operation. Their findings suggest that the ganglion cells in pyloric stenosis, though present in adequate numbers, are immature. We have repeated their investigations and although we have not enough material, the present significant findings are in agreement with them. It would be in keeping with most of the observed facts if babies developed this condition because the innervation of the pylorus was 'premature'. Pooling the resources of a number of centres should make it possible to assess this theory.
Blair P (1717) Phil. Trans., 30 , 31 SERCES

Burghard, F. F. (1906). Quoted by Stiles, H. J. in Brit. med. J., 2, 943

Cautley, E. (1899). Med.-chir. Trans., 82, 41.

- (1904). Brit. J. Child. Dis., 1, 10.

(1906) Brit med J 2,939 .

(1908). Brit. J. Child. Dis., 5,179

- and Dent, C. T. (1903). Med.-chir. Trans., 86, 471.

Fredet, P. (1921). Bull. Soc. Chir. Paris, 47, 451 . 34, 789.

— and Guillemot, L. (1910). Congrés de Gynécologie, d'Obstétrique, et de Pédiatrie.

and Tixier, L. (1912). Ibid., 34, 868.

Friesen, S. R., Boley, J. O. and Miller, D. R. (1956). Surgery, $39,21$.

Hirschsprung, H. (1888). Jb. Kinderheilk., $27,1$.

Loreta, P. (1884). La divulsione digitale del piloro e la divulsione strumentale dell'esofago e del cardias invece della gastrotomia, 2nd ed. Treves, Bologna.

- (1887). Gazz. Osp., 8, 803.

Mack, H. C. (1942). Bull. Hist. Med., 12, 465, 595 and 666.

Nicoll, J. (1900). Brit. med. J., 2, 571 .

(1904). Ibid., 2, 1148 .

(1906). Glasg. med. J., 65, 253.

- (1910). Practitioner, 85, 659.

Pollock, W. F. and Norris, W. J. (1957). Surgery, 42, 966.

- , and Gordon, H. E. (1957). Amer. J. Surg., 94, 335

Rammstedt, C. (1912). Med. Klin., 8, 1702

(1913). Zbl. Chir., 40, 3.

Ramsay, R. A. (1919). Trans. med. Soc. Lond., 42, 125.

(1921). Brit. J. Surg., 8, 397.

Ramstedt, C. (1922). Zbl.' Chir., 49, 1329.

- (1957). Personal communication.

Weber, C. (1758). Cited by Still, G. F. (1931). The History of Paediatrics, p. 400 . Oxford University Press.

Weber, W. (1909). Münch. med. Wschr., 56, 1617.

Will (1910). Berl. klin. Wschr., 47, 763. Williamson, T. (1841). London and Edinburgh Monthly Journal of
Medical Science, 1, 23 . 